\title{
The influence of patient's motivation on reported pain during orthodontic treatment
}

\author{
Marcio José da Silva Campos¹, Robert Willer Farinazzo Vitral²
}

Introduction: Patients usually experience pain during orthodontic treatment. This fact can affect cooperation and the development of treatment. Reporting pain during treatment seems to be influenced by emotional aspects such as the patient's motivation. Objective: To assess the relationship between patient's motivation and the intensity of reported pain during two stages of treatment. Methods: Twenty males (11-37 years old) answered a questionnaire divided into five categories regarding their motivation towards treatment. The subjects were studied for 14 days $(7$ days with bonded brackets and 7 days with the initial arch inserted) and the intensity of pain was evaluated on a daily basis. All the issues, including the intensity of pain, were measured through the visual analog scale (VAS). Results: The VASassociated questionnaire proved to have good temporal reliability and reasonable internal consistency, being that the "perceived severity" domain had the greatest, although not significant $(\mathrm{p}=0.196)$ correlation with pain intensity. Only the question asking the patients if they thought that their teeth were too uneven showed a positive correlation with pain intensity $(p=0.048)$. Conclusion: The results seem to indicate that the five categories related to treatment motivation cannot be used to predict discomfort during treatment. In addition, patients who think their teeth are too uneven may experience more severe pain due to greater force application after insertion of the initial arch.

Keywords: Pain. Orthodontics. Motivation.

Introdução: experiências de dor são relatadas rotineiramente pelos pacientes durante o tratamento ortodôntico, o que pode prejudicar a cooperação e o desenvolvimento do tratamento. Os relatos de dor parecem ser influenciados por fatores emocionais, como a motivação para o tratamento. Objetivo: avaliar a correlação existente entre a motivação para o tratamento ortodôntico e a intensidade de dor relatada pelos pacientes durante duas fases iniciais do tratamento. Métodos: vinte indivíduos homens, com 11 a 37 anos de idade, foram avaliados por meio de um questionário dividido em cinco domínios relacionados à motivação para tratamento ortodôntico. Os indivíduos foram acompanhados durante 14 dias, sendo 7 dias apenas com os braquetes colados e 7 dias com o arco inicial inserido, sendo a intensidade de dor avaliada diariamente. Todas as questões, assim como intensidade da dor, foram mensuradas por meio da Escala Visual Análoga (EVA). Resultados: o questionário associado à EVA apresentou boa confiabilidade temporal e consistência interna razoável, sendo que o domínio "Severidade percebida" apresentou a maior correlação com a intensidade de dor, apesar de não significativa $(\mathrm{p}=0,196)$. $\mathrm{Na}$ análise das questões, apenas a que avaliou se os pacientes julgavam seus dentes muito tortos apresentou correlação positiva com a intensidade de dor $(p=0,048)$. Conclusão: os resultados indicam que os cinco domínios relacionados à motivação para o tratamento ortodôntico não podem ser utilizados para predizer o desconforto durante o tratamento, porém o fato de o indivíduo julgar seus dentes tortos pode indicar experiências de dor mais intensas devido à maior aplicação de força após a inserção do arco inicial.

Palavras-chave: Medição da dor. Motivação. Ortodontia.

${ }^{1}$ Professor, Specialization Course in Orthodontics, UFJF.

${ }^{2}$ Associate Professor, Department of Orthodontics and Pediatric Orthodontics, UFJF.

» The authors report no commercial, proprietary or financial interest in the products or companies described in this article.
How to cite this article: Campos MJS, Vitral RWF. The influence of patient's motivation on reported pain during orthodontic treatment. Dental Press J Orthod. 2013 May-June;18(3):80-5.

Submitted: January 10, 2010 - Revised and accepted: August 09, 2010

Contact address: Marcio José da Silva Campos

Rua Paracatu, 568 - Bairro Santa Terezinha - Juiz de Fora/MG - Brazil

CEP: 36.046-040 - E-mail: drmarciocampos@hotmail.com 


\section{INTRODUCTION}

Success of orthodontic treatment is often dependent on the use of devices and techniques to minimize patient's discomfort, once pain and discomfort hamper cooperation, leading to poor adherence to follow-up and treatment interruption. ${ }^{22}$ Pain is commonly assessed through the Visual Analogue Scale (VAS), 2,7,8,9,15,17,21,24,25,27,29 which records the subjective experience of pain.

Pain during orthodontic treatment is reported by up to $95 \%$ of the patients, ${ }^{20,25}$ being associated with trauma to the buccal mucosa ${ }^{2,20,21}$ and application of force to the teeth. ${ }^{2,3,7,8,13,15,21,22,25}$ Yet, because pain is strongly related to emotional, cognitive and cultural factors, ${ }^{2,12}$ the intensity is modulated by the individual's personality. ${ }^{15,16}$

Subjective factors, such as self-perception of dental status and esthetic, greatly influence the individual's willingness to undergo orthodontic treatment. ${ }^{1,16,21}$ These factors, along with the patient's information on the orthodontic treatment, make up treatment motivation. The degree of motivation may influence pain perception during treatment, with patients who are willing to undergo treatment or find their malocclusion severe enough reporting lower pain levels. ${ }^{26}$

This study aimed to assess the correlation between patient's motivation and pain intensity, reported during the initial phases of orthodontic treatment.

\section{MATERIAL AND METHODS}

Twenty male individuals, aged from 11 to 37 years (mean age $18.5 \pm 6.2$ years), who sought orthodontic treatment, were selected after the following criteria were satisfied: Absence of deciduous teeth; no previous orthodontic treatment; good general health; and no periodontal disease.

Because pain experience is influenced by emotional, cognitive and motivational characteristics, and also by family behavior patterns, ${ }^{2,18}$ the following subjects were excluded from the study: Dentists; dental students; close relatives or partners of Dentists or individuals who had used a fixed appliance in the preceding 12 months; individuals who feared dental treatment; and those on psychotropic drugs (antipsychotics, benzodiazepines, anticonvulsants or antidepressants), anti-inflammatory drugs and analgesics.

This study was approved by the Research Ethics Committee of the Federal University of Juiz de Fora.
All participants were volunteers and signed their informed consent after a thorough explanation of the procedures to be undertaken.

In the initial consultation, patient's motivation to undergo orthodontic treatment was assessed through a 27-question questionnaire, divided into 5 domains: Perceived Severity, Dental Esthetic, Willingnessto-Treat, Treatment Perception and Occlusion Importance. The questions were answered through a $100 \mathrm{~mm} \mathrm{VAS},{ }^{11}$ (Fig 1) which varied according to Table 1. Only one examiner applied the questionnaire, informing the participants about the way to fill it in, but without providing further information on the questions. The VAS value was calculated as the distance in millimeters from the left end of the horizontal line to the center of the mark made by the patient, the value for each domain consisting of the arithmetic mean of the corresponding answers.

In order to assess the reliability of the 27 questions, and determine their temporal stability, a pre-questionnaire was applied twice, to 20 individuals, with a mean interval of 42.7 days between applications.

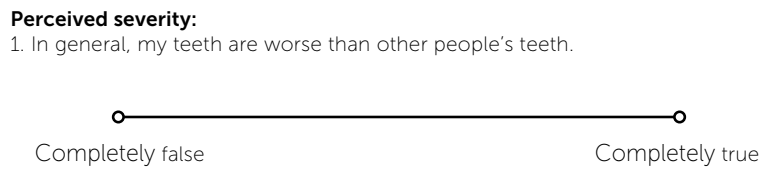

Figure 1 - Question 1 of the 100 mm Visual Analogue Scale.

\begin{tabular}{|c|c|c|}
\hline Domains & Questions & VAS variation \\
\hline $\begin{array}{l}\text { Perceived } \\
\text { severity }\end{array}$ & 1 to 7 & $\begin{array}{l}\text { Completely true / } \\
\text { Completely false }\end{array}$ \\
\hline Dental esthetic & 8 to 10 & $\begin{array}{l}\text { Completely true / } \\
\text { Completely false }\end{array}$ \\
\hline \multirow{3}{*}{$\begin{array}{l}\text { Willingness-to- } \\
\text { treat }\end{array}$} & 11 to 14 & $\begin{array}{l}\text { Completely true / } \\
\text { Completely false }\end{array}$ \\
\hline & $15-16$ & Totally disagree / totally agree \\
\hline & $17-18$ & Definitely not / definitely yes \\
\hline $\begin{array}{l}\text { Treatment } \\
\text { perception }\end{array}$ & 19 to 25 & Totally disagree / totally agree \\
\hline $\begin{array}{l}\text { Occlusion } \\
\text { importance }\end{array}$ & $26-27$ & Without importance / very important \\
\hline
\end{tabular}


Patient assessment lasted 14 days and was divided into 2 phases: Bonding (days 1-7) and initial arch (days 8-14). On the morning of the day preceding assessment onset, brackets and tubes (Mini Standard Edgewise, American Orthodontics, Wisconsin, USA) were bonded to the vestibular surfaces of the maxillary incisors, canines, premolars and first molars. On the morning of day 7, a 0.014-in pre-formed archwire (Titanium Memory Wire, American Orthodontics, Wisconsin, USA) was totally inserted in the slots of all brackets and tubes, being then fixed with a 0,010 -in steel ligature wire.

Pain intensity was recorded daily during the 14 study days, at wake-up time. Two $100 \mathrm{~mm}$ VAS were used, one for tooth pain and the other for buccal mucosa pain, with a range from "without pain" to "worst pain ever", measurements being taken similarly to the procedure used in the questionnaire. Pain intensity was the arithmetic mean of the VAS for tooth pain and buccal mucosa pain.

\section{STATISTICAL ANALYSIS}

The test-retest reliability of the questions from each domain of the pre-questionnaire was assessed by the Interclass Correlation Coefficient (ICC), based on variance analysis. The internal consistency of each domain was assessed through Cronbach's alpha coefficient. Pearson's Correlation Coefficient assessed the relationship between the questionnaire domains and pain intensity means, and between each question and pain intensity means. The Statistical Package for the Social Sciences (SPSS 11.0.0) program was used for the analyses.

\section{RESULTS}

Analysis of the pre-questionnaire, which determined the ICC, showed excellent reliability (ICC > 0.75) for the Dental Esthetic, Treatment Perception and Occlusion Importance domains, and good reliability $(0.4<$ ICC $<0.75)$ for the Perceived Severity and Willingness-to-Treat domains (Table 2).

Based on the applied questionnaire, Cronbach's alpha coefficient was calculated for the estimation of the internal consistency of each domain (Table 2). The Occlusion Importance domain had very good internal consistency $(\alpha>0.9)$, the Perceived Severity and Treatment Perception domains had good consis- tency ( $\alpha$ between 0.8 and 0.9 ), the Willingness-toTreat domain had regular consistency ( $\alpha$ between 0.7 and 0.8), and the Dental Esthetic domain had weak consistency ( $\alpha$ between 0.6 and 0.7 ). ${ }^{23}$

The pain intensity means reported by the patients every day of the study period are shown in Figure 2. The correlations between each domain of the questionnaire of assessment of treatment motivation and the pain intensity means are shown in Table 3. No significant correlation was found for any domain. Tables 4 to 8 show the correlation between each question and pain intensity. Only question 2 showed a significant positive correlation.

Table 2 - Test-retest reliability and internal consistency of each questionnaire domain.

\begin{tabular}{lcc}
\hline Domains & ICC* & $\alpha^{\star \star}$ \\
\hline Perceived severity & $0.71(0.60-0.80)$ & 0.83 \\
Dental esthetic & $0.79(0.65-0.88)$ & 0.62 \\
Willingness-to-treat & $0.71(0.60-0.79)$ & 0.70 \\
Treatment perception & $0.81(0.73-0.86)$ & 0.83 \\
Occlusion importance & $0.83(0.67-0.91)$ & 0.98 \\
\hline
\end{tabular}

* Interclass correlation coefficient with 95\% confidence interval;

** Cronbach's alpha coefficient.

Table 3 - Correlation between the questionnaire domains and pain intensity.

\begin{tabular}{ccccc}
\hline Domains & \multicolumn{2}{c}{ Value (VAS) } & $\begin{array}{c}\text { Coefficient of } \\
\text { correlation with } \\
\text { pain intensity }\end{array}$ & $\begin{array}{c}\text { Significance } \\
\text { (p value) }\end{array}$ \\
$\begin{array}{c}\text { Perceived } \\
\text { severity }\end{array}$ & 58.0 & $0-93$ & 0.302 & 0.196 \\
$\begin{array}{c}\text { Dental } \\
\text { esthetic }\end{array}$ & 75.1 & $33-100$ & 0.096 & 0.687 \\
$\begin{array}{c}\text { Willingness- } \\
\text { to- treat }\end{array}$ & 69.6 & $25-100$ & 0.134 & 0.574 \\
$\begin{array}{c}\text { Treatment } \\
\text { perception }\end{array}$ & 65.7 & $0-100$ & 0.101 & 0.673 \\
$\begin{array}{c}\text { Occlusion } \\
\text { importance }\end{array}$ & 91.5 & $58-100$ & -0.006 & 0.981 \\
\hline
\end{tabular}


Table 4 - Correlation between the questions of the Perceived Severity domain and pain intensity

\begin{tabular}{lcc}
\hline \multicolumn{1}{c}{ Questions } & $\begin{array}{c}\text { Correlation } \\
\text { coefficient }\end{array}$ & $\begin{array}{c}\text { Significance } \\
\text { (p value) }\end{array}$ \\
$\begin{array}{l}\text { 1. In general, my teeth are worse than } \\
\text { the teeth of other people }\end{array}$ & -0.124 & 0.602 \\
$\begin{array}{l}\text { 2. My teeth are too crooked } \\
\text { 3. My teeth really need correcting }\end{array}$ & 0.447 & $0.048^{*}$ \\
$\begin{array}{l}\text { 4. I am not happy with the appearance } \\
\text { of my teeth when I bite }\end{array}$ & 0.261 & 0.267 \\
$\begin{array}{l}\text { 5. I am worried about the appearance of } \\
\text { my teeth when I bite }\end{array}$ & 0.013 & 0.955 \\
$\begin{array}{l}\text { 6. My crooked teeth bother me } \\
\text { 7. My teeth don't look nice the way } \\
\text { they are }\end{array}$ & 0.266 & 0.187 \\
\hline
\end{tabular}

* $p<0.05$ according to Pearson's test

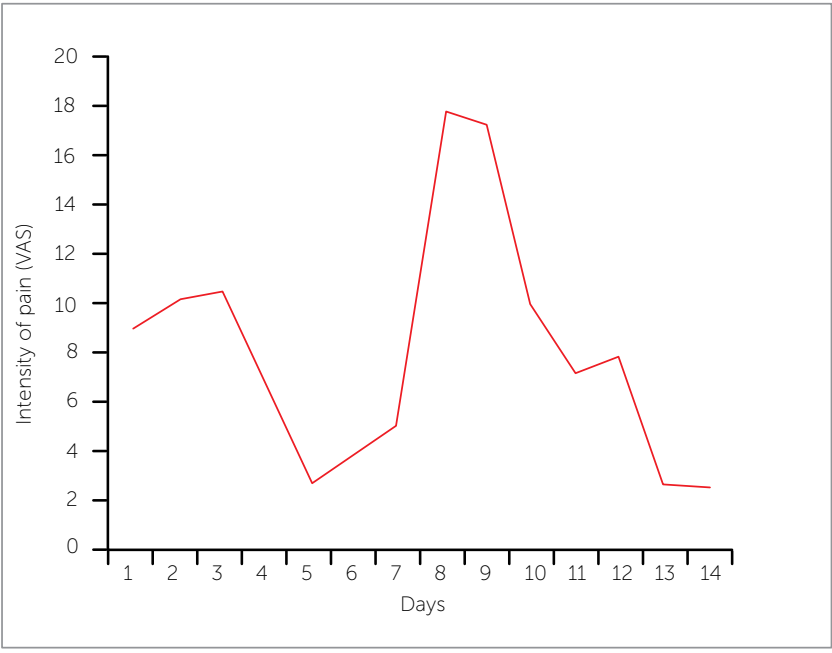

Figure 2 - Intensity of patients' reported pain during the bonding (days 1 to 7 ) and initial arch (days 8 to 14) phases.

Table 5 - Correlation between the Dental Esthetic domain questions and pain intensity.

\begin{tabular}{lc}
\hline \multicolumn{1}{c}{ Questions } & Correlation coefficient \\
8. A beautiful smile is important & -0.005 \\
9. The teeth are the most important contributor to the beauty of people's faces & 0.982 \\
10. When I see people's faces, the first point I'm generally drawn to are the teeth & 0.106 \\
\hline
\end{tabular}

Table 6 - Correlation between the Willingness-to-treat domain questions and pain intensity.

\begin{tabular}{lc}
\hline \multicolumn{1}{c}{ Questions } & Correlation coefficient \\
\hline 11. I think about using a tooth appliance & 0.186 \\
12. I would be happy to treat my teeth with an orthodontic appliance & 0.174 \\
13. I wish I could afford to have my teeth aligned & 0.298 \\
14. I want to have my teeth aligned & 0.107 \\
15. People who use a fixed appliance are luckier than I am & 0.119 \\
16. Even if it is costly, it pays to have my teeth aligned & -0.118 \\
17. I'm willing to use a fixed appliance for a long time & -0.088 \\
18. I'm willing to tolerate bouts of pain during the orthodontic treatment & 0.203 \\
\hline
\end{tabular}

Table 7 - Correlation between the Treatment Perception domain questions and pain intensity.

\begin{tabular}{lcc}
\hline \multicolumn{1}{c}{ Questions } & $\begin{array}{c}\text { Correlation } \\
\text { coefficient }\end{array}$ & $\begin{array}{c}\text { Significance } \\
\text { (p value) }\end{array}$ \\
$\begin{array}{l}\text { 19. People who use fixed appliances don't } \\
\text { look silly }\end{array}$ & 0.212 & 0.370 \\
$\begin{array}{l}\text { 20. A fixed appliance doesn't make the } \\
\text { teeth look ugly }\end{array}$ & -0.067 & 0.780 \\
\hline 21. I can see myself using a fixed appliance & 0.238 & 0.311 \\
\hline $\begin{array}{l}\text { 22. Using a fixed appliance is not worse } \\
\text { than wearing glasses }\end{array}$ & -0.210 & 0.374 \\
\hline $\begin{array}{l}\text { 23. Using a fixed appliance would not } \\
\text { bother me at all }\end{array}$ & 0.275 & 0.241 \\
\hline $\begin{array}{l}\text { 24. People who use a fixed appliance seem } \\
\text { not to perceive them }\end{array}$ & 0.099 & 0.678 \\
\hline $\begin{array}{l}\text { 25. The fixed appliance is not going to } \\
\text { bother me }\end{array}$ & 0.023 & 0.924 \\
\hline
\end{tabular}

Table 8 - Correlation between the Occlusion Importance domain questions and pain intensity.

\begin{tabular}{lcc}
\hline \multicolumn{1}{c}{ Questions } & $\begin{array}{c}\text { Correlation } \\
\text { coefficient }\end{array}$ & $\begin{array}{c}\text { Significance } \\
\text { (p value) }\end{array}$ \\
$\begin{array}{l}\text { 26. In your opinion, what is the } \\
\text { importance of having aligned teeth } \\
\text { that articulate correctly? }\end{array}$ & -0.046 & 0.847 \\
27. In your opinion, for a person whose & & \\
teeth are crooked and do not & & \\
articulate correctly, what is the & 0.038 & \\
\hline importance of having aligned teeth? & & \\
\hline
\end{tabular}




\section{DISCUSSION}

The high prevalence rates of pain reported by patients during orthodontic treatment $\mathrm{t}^{2,3,7,8,13,15,19-22,25}$ may lead to treatment failure due to lack of adherence $^{5,22}$ and treatment drop-out. ${ }^{22}$ Thus, it is important to search for factors that may influence the prevalence and intensity of the pain experienced by these patients.

Authors ${ }^{3,15}$ suggested that psychological factors might somehow influence the reports of pain and discomfort. Among such factors, patient's motivation to undergo orthodontic treatment seems to be the most relevant. ${ }^{1,16,26}$

Patient's motivation has been studied through self-assessment of the dental condition, ${ }^{10,28}$ esthetic perception $^{1,10,16,21}$ and knowledge about the orthodontic treatment. ${ }^{10}$ In this study, patient's motivation was assessed through a questionnaire based on the works of Clemmer and Hayes ${ }^{4}$ and Fox et al. ${ }^{10}$ The 27 questions addressed: 1) perception of the severity of the dental problem; 2) importance of dental esthetic; 3) willingness to undergo orthodontic correction; 4) impressions about the orthodontic treatment; and 5) importance of good occlusion.

The questions were answered according to a VAS, a widely used scale to assess pain intensity, $2,7,8,9,15,17,21,24,25,27,29$ and which has been used in some questionnaires. ${ }^{2,6,30}$ The reliability test showed a good to excellent precision for all questionnaire domains, pointing to the good assessment stability of VAS-associated questions at different times.

Although the patients were motivated to undergo the treatment, with domain values ranging from 58 to 91 (VAS), there was no significant correlation between the degree of motivation and the reported pain intensity. This happened when the questions were analyzed by domains or individually, except for question 2. These results agree with other studies, which failed to find a correlation between pain intensity and dentofacial esthetic, or with the selfperceived treatment need. ${ }^{1,8}$

Although no domain was significantly correlated with pain intensity, Perceived Severity had the lowest $p$ value (0.196), with a positive correlation. Contrary to this trend, Sergl et $\mathrm{al}^{26}$ found a negative correlation, indicating that patients who perceived their malocclusion to be more severe reported less intense pain.

The significance of the Perceived Severity domain was influenced by question 2 , the only one that showed a significant positive correlation with pain intensity. Because this question assessed whether the patient considers their teeth to be "very crooked", the result highlights the hypothesis that the intensity of force application to the teeth, regardless of the degree of tooth crowding, has a relationship with pain reported during the alignment and leveling phase, ${ }^{2}$ although other studies have not confirmed this relationship. ${ }^{14,15}$

The existence of a relationship between the degree of dental crowding and pain intensity is a reminder of the importance of educating patients on the possibility of more intense pain, proportional to the severity of dental crowding, chiefly after insertion of the initial arch during the alignment and leveling phase.

\section{CONCLUSION}

The results indicate that the intensity of reported pain during orthodontic treatment is not related to treatment motivation, evidencing no rationale to use the degree of a patient's motivation to predict discomfort experienced after installation and activation of the orthodontic appliance. 


\section{REFERENCES}

1. Bergius $M$, Berggren $U$, Kiliaridis $S$. Experience of pain during an orthodontic procedure. Eur J Oral Sci. 2002 Apr;110(2):92-8.

2. Bergius $M$, Kiliaridis $S$, Berggren U. Pain in orthodontics: a review and discussion of the literature. J Orofac Orthop. 2000;61(2):125-37.

3. Brown DF, Moerenhout RG. The pain experience and psychological adjustment to orthodontic treatment of preadolescents, adolescents, and adults. Am J Orthod Dentofacial Orthop. 1991;100(4):349-56.

4. Clemmer EJ, Hayes EW. Patient cooperation in wearing orthodontic headgear. Am J Orthod. 1979;75(5):517-24

5. Egolf RJ, BeGole EA, Upshaw HS. Factors associated with orthodontic patient compliance with intraoral elastic and headgear wear. Am J Orthod Dentofacial Orthop. 1990;97(4):336-48.

6. Feldmann I, List T, John MT, Bondemark L. Reliability of a questionnaire assessing experiences of adolescents in orthodontic treatment. Angle Orthod. 2007:77(2):311-7

7. Fernandes LM, Ogaard B, Skoglund L. Pain and discomfort experienced after placement of a conventional or a superelastic NiTi aligning archwire. A randomized clinical trial. J Orofac Orthop. 1998;59(6):331-9.

8. Firestone AR, Scheurer PA, Bürgin WB. Patients' anticipation of pain and painrelated side effects, and their perception of pain as a result of orthodontic treatment with fixed appliance. Eur J Orthod. 1999:21(4):387-96.

9. Fleming PS, Dibiase AT, Sarri G, Lee RT. Pain experience during initial alignment with a self-ligating and a conventional fixed orthodontic appliance system - a randomized controlled clinical trial. Angle Orthod 2009:79(1):46-50

10. Fox RN, Albino JE, Green LJ, Farr SD, Tedesco LA. Development and validation of a measure of attitudes toward malocclusion. J Dent Res. 1982:61(9):1039-43

11. Huskisson EC. Measurement of pain. Lancet. 1974:9(7889):1127-31.

12. International Association for the Study of Pain. Pain terms: a list with definitions and notes on usage. Pain. 1979;6(3):249-52

13. Jones ML. An investigation into the initial discomfort caused by placement of an archwire. Eur J Orthod. 1984;6(1):48-54

14. Jones ML, Richmond S. Initial tooth movement: force application and pain: a relationship? Am J Orthod. 1985:88(2):111-6

15. Jones M, Chan C. The pain and discomfort experienced during orthodontic treatment: a randomized controlled clinical trial of two initial aligning arch wires. Am J Orthod Dentofacial Orthop. 1992;102(4):373-81.

16. Kiliaridis S, Bergius M. Pain and discomfort in orthodontics. In: Graber TM, Eliades T, Athanasiou A. E. Risk management in Orthodontics: experts guide to malpractice. Chicago: Quintessence; 2004. p. 131-43.

17. Kluemper GT, Hiser DG, Rayens MK, Jay MJ. Efficacy of a wax containing benzocaine in the relief of oral mucosal pain caused by orthodontic appliances. Am J Orthod Dentofacial Orthop. 2002;122(4):359-65.

18. Krishnan V. Orthodontic pain: from causes to management-a review. Eur J Orthod. 2007:29(2):170-9

19. Kvam E, Bondevik O, Gjerdet NR. Traumatic ulcers and pain in adults during orthodontic treatment. Community Dent Oral Epidemiol. 1989:17(3):154-7.

20. Kvam E, Gjerdet NR, Bondevik O. Traumatic ulcers and pain during orthodontic treatment. Community Dent Oral Epidemiol. 1987:15(2):104-7.
21. Ngan P, Kess B, Wilson S. Perception of discomfort by patients undergoing orthodontic treatment. Am J Orthod Dentofacial Orthop. 1989;96(1):47-53

22. Oliver RG, Knapman YM. Attitudes to orthodontic treatment. Br J Orthod. 1985:12(4):179-88

23. Pestana MH, Gagueiro JN. Análise de dados para Ciências Sociais. 4a ed. Lisboa: Síbalo; 2005

24. Polat $O$, Karaman Al. Pain control during fixed orthodontic appliance therapy. Angle Orthod. 2005:75(2):214-9.

25. Scheurer PA, Firestone AR, Burgin WI. Perception of pain as a result of orthodontic treatment with fixed appliances. Eur J Orthod. $1996: 18(4): 349-57$

26. Sergl HG, Klages $U$, Zentner A. Pain and discomfort during orthodontic treatment. Causative factors and effects on compliance. Am J Orthod Dentofacial Orthop. 1998;114(6):684-91.

27. Seymour RA, Simpson JM, Charlton JE, Phillips ME. An evaluation of length and end-phrase of visual analogue scales in dental pain. Pain. 1985:21(2):177-85

28. Shaw WC, Addy M, Ray C. Dental and social effects of malocclusion and effectiveness of orthodontic treatment: a review. Community Dent Oral Epidemiol. 1980;8(1):36-45

29. Shirasaki S, Fujii H, Takahashi M, Sato T, Ebina M, Noto Y, Hirota K. Correlation between salivary - amylase activity and pain scale in patients with chronic pain. Reg Anesth Pain Med. 2007;32(2):120-3.

30. Ziuchkovski JP, Fields HW, Johnston WM, Lindsey DT. Assessment of perceived orthodontic appliance attractiveness. Am J Orthod Dentofacial Orthop. 2008:133(4 Suppl):S68-78 